\title{
The Meaning of the Presumption of Innocence for Pre-trial Detention
}

\section{An Empirical Approach}

Lonneke Stevens

\section{Introduction}

What is the presumption of innocence (PoI)? In a nutshell, Anthony Duff's thought provoking argument purports that there is not one but many (interconnected) PoI. One of those is an important principle for restricting pre-trial detention. Duff's account of the meaning of the PoI is intellectually challenging and a pleasure to read. Duff takes a normative point of view - how should the PoI regulate pre-trial detention. He is not primarily concerned with how the PoI actually regulates pre-trial detention and how it is practiced. My contribution will particularly focus on the latter perspective. Accordingly, section 3 describes the results of my empirical research into the argumentation of Dutch judges (for what reasons do they order pre-trial detention?) and also outlines several other national practices. Hence, I will confront Duff's normative PoI based pre-trial detention theory with pre-trial detention practice. But first, in section 2, in order to better understand Duff's position, I will discuss the relation between the PoI and pre-trial detention as seen by Duff, other scholars, and the European Court of Human Rights (ECtHR). The central question to this contribution thus is: what can be seen of (Duff's or other) PoI in pre-trial detention practice?

\section{The Relation between the PoI and Pre-trial Detention}

What is, according to Duff, the PoI and its relation to pre-trial detention? Duff bases his PoI on the civic trust that holds society together. Important within the civic trust theory are the different normative roles of citizens, suspects/defendants $^{1}$ and convicts. Duff considers that these are capacities with different normative roles in society. This implies that the trust that is reasonably due to them in social relations (including in the sphere of criminal justice) differs. Since - for good reasons - the level of trust associated with the role of the suspect is less than the role associated with a non-suspect citizen, Duff speaks of a 'qualified' PoI. Because of the different level of trust it is legitimate to subject the suspect to a (reasonable) system of bail. A system of bail is consistent with the PoI because

1 I will further only use the term 'suspect.' The Dutch system does not use the term 'defendant' and does not make an explicit distinction between suspects and defendants. 'Suspect' is used in both pre-trial and trial stage, before and after official charges have been made. A suspect in pretrial detention is a suspect in the pre-trial stage who is criminally charged. 
of the responsibility of the suspect to re-establish that trust. This is different for pre-trial detention. Duff considers pre-trial detention an infringement of the civic trust based PoI. The reason is that a pre-detained suspect is treated as entirely untrustworthy and, as I understand Duff, this complete distrust does not fit the normative role of the suspect. This infringement of the PoI has, as Duff puts it, 'significant implications concerning the conditions under which defendants can be detained (...).' Detention for crime-preventive reasons for example, is only acceptable in exceptional cases.

Now, the concept of a civic trust based PoI has never, to my mind, been put forward by other scholars. However, Duff does stand in a tradition in which the PoI is assumed to be an argument for restricting pre-trial detention. But whereas agreement exists about the importance of the PoI for pre-trial detention, opinions differ as to which criteria follow from the PoI. Some scholars accept the grounds of risk of repetition (about which Duff is critical) and risk of public disorder (Duff does not mention the latter; I presume he is critical at the least). Others consider these grounds to be an unacceptable violation of the PoI, or plead for a 'public disorder ground' that is restricted to protecting the suspect from an angry public. Some scholars, like Duff, stress that the PoI demands very strong evidence in order to legitimize pre-trial detention. The pre-trial detention system that scholars plead for also seems to resemble their own. Dutch scholars for example, think their legislative model of pre-trial detention is in accordance with the PoI. ${ }^{2}$ In short, the PoI is put forward as a fundamental principle regulating and restricting pre-trial detention, but subsequently invoked to either justify or reject the same criteria for pre-trial detention. Thus, the first point worth noting is that the PoI does not seem to be a discriminating argument for or against a certain choice regarding the regulation of pre-trial detention. The second relevant characteristic of the discussion on the PoI and pre-trial detention concerns the case law of the ECtHR. The Court stresses that the PoI is the fundamental starting point for pretrial detention decisions. At the same time, its criteria are not as strict as the criteria accepted by the above mentioned scholars. The risk of repetition and public disorder are accepted grounds for pre-trial detention. Public disorder is not interpreted restrictedly; the Court seems to allow the gravity of an offence to largely substantiate the ground. Also, the ECtHR accepts a reasonable suspicion for a certain - sometimes quite lengthy - period of pre-trial detention. ${ }^{3}$ In general, the Court does not seem to consider many practices of pre-trial detention a violation of the PoI. On a concrete level the PoI therefore does not seem to restrict pre-trial

2 M.S. Groenhuijsen, 'De nabije toekomst van de voorlopige hechtenis, in het bijzonder in het licht van de onschuldpraesumptie,' in Door Straatsburg geïnspireerde grondnormen voor het Nederlandse strafproces, ed. J. de Hullu et al. (Deventer: W.J.D. Tjeenk Willink, 2000), 87-96; N. Keijzer, 'Enkele opmerkingen omtrent de praesumptio innocentiae in strafzaken', in Naar eer en geweten, ed. Ch.J. Enschedé et al. (Arnhem: Gouda Quint, 1987), 235-53.

3 See for a more profound study on the different opinions and for a description of the case law of the ECtHR L. Stevens, 'Pre-Trial Detention: The Presumption of Innocence and Article 5 of the European Convention on Human Rights Cannot and Do Not Limit its Increasing Use,' European Journal of Crime, Criminal Law and Criminal Justice 17 (2009): 167-71. 
detention to a minimum as it - according to Duff and other scholars - ideally should.

\section{Confronting PoI Based Pre-trial Detention with Pre-trial Detention Practice}

\subsection{Research into Judicial Argumentation}

\subsubsection{Research Design, Background and Legal Framework}

Section 2 discussed the difference between the ideas of how the PoI should restrict pre-trial detention and how pre-trial detention is regulated by the case law of the ECtHR. Another question concerns the relation between regulation and pre-trial detention practice. I have studied the use of pre-trial detention in the Netherlands by interviewing 28 Dutch judges in semi-structured interviews. Judges were asked to comment on five different cases and explain whether and why they would pre-detain this suspect. They were furthermore asked open questions about their arguments for pre-trial detention. ${ }^{4}$ The research followed from a lack of case law on pre-trial detention. In the Netherlands, judicial pre-trial detention decisions are rarely published and scarcely motivated. Also, pre-trial detention practice has been the concern of criminal defence lawyers and scholars for many years: they believe grounds for pre-trial detention are too easily accepted and the use of pre-trial detention is ever increasing. Most criticized are the risk of repetition and the risk of a seriously shocked legal order in case of a crime that is punished with imprisonment of twelve years or more. ${ }^{5}$ Since it is argued that the PoI demands a strict interpretation and sound substantiation of these grounds, ${ }^{6}$ the five mentioned cases focused on them.

My findings will be discussed in the following sections. Since the judges' answers need to be understood within the context of Dutch legislation on pre-trial detention the following is relevant to know. Besides the legal grounds, Dutch pre-trial detention can only be ordered in case the crime committed is serious to a certain extent and if there are 'grave suspicions' ('ernstige bezwaren'). Serious crimes are crimes the law punishes with four year imprisonment minimum, and several other crimes that are specifically mentioned in article 67 of the Code of Criminal

4 An extensive account of the research can be found in L. Stevens, 'Incapacitation by Pre-trial Detention,' in Incapacitation: Trends and New Perspectives, ed. M. Malsch et al. (Surrey: Ashgate Publishing, 2012), 97-108. Also L. Stevens, 'Voorlopige hechtenis in tijden van risicomanagement. Lijdende of leidende beginselen?,' Delikt en Delinkwent 40 (2012): 382-405.

5 The Dutch Code of Criminal Procedure recognizes four grounds for pre-trial detention that are similar to the ones distinguished by the European Court of Human Rights. They are: the risk of flight, the risk of collusion, the risk of repetition and the seriously shocked legal order (equivalent to 'public disorder') concerning crimes that are punished with imprisonment of twelve years minimum.

6 See literature discussed in L. Stevens, 'De praktijk van de Nederlandse voorlopige hechtenis vanuit Straatsburgs perspectief: “klaag niet te snel," Delikt en Delinkwent 35 (2009): 499-514. 
Procedure. ${ }^{7}$ The standard of 'grave suspicions' means that there has to be more than a 'reasonable suspicion,' which is the standard for arrest and police custody. How much more this must be, or how strict the standard of grave suspicions is, is not very clear. Furthermore, fixed time limits exist to prevent detention from lasting endlessly. The maximum period during which a suspect can be held in pretrial detention before the start of the trial is set at 104 days. $^{8}$

\subsubsection{Dangerousness and Incapacitation: the First-aid Kit of Pre-trial Detention}

Crucial within the judicial argumentation appears to be the seriousness of the suspected crime. Judged serious by all means, are offences that involve some kind of violence or an attempt at violence against individuals. 'Seriousness' in the judicial argumentation is used to substantiate both the ground of the shocked legal order and the risk of repetition. With regard to the first ground the emphasis lies on demonstrating to the public that serious crimes will not be tolerated. 'I think it is important,' one judge says, 'that people feel that they can move freely and without fear of becoming a victim.' As such, the ground of the seriously shocked legal order is solely based on the gravity of the offence. It focuses on the danger that is felt by citizens when they hear a serious crime is committed. Pretrial detention on the basis of this ground is a reassurance that measures are taken to prevent other citizens becoming a victim too.

The same need to protect from dangerousness substantiates the risk of repetition. With this ground, however, the emphasis is on the person of the perpetrator instead of the crime. A crime of a certain serious nature is easily judged as 'incomprehensible,' or 'dangerous,' and hence the suspect as 'a dangerous person.' It even seems to follow from the argumentation that the absence of a criminal record pleads against the suspect. 'Why would someone do something this bad out of the blue? He might as well do it again,' judges reason. In order to prevent the danger to happen judges order the pre-trial detention of the suspect. To my mind, this line of reasoning basically implies that the risk of repetition is given with the suspicion of a serious offence. 'Serious is dangerous,' as one could say. The latter also entails that establishing a risk of repetition strongly depends on society's disapproval of certain conduct. The more serious a crime, the more dangerous the suspect, the larger a risk of reoffending.

Some judges acknowledge that the risk of reoffending is a ground that can always be construed. 'The risk of reoffending is present if you need it to be,' one judge says. The ground is kind of a 'garbage bin,' as another judge puts it. But for what reasons then, would a judge 'need' the ground of the risk of repetition? I would argue this is already more or less implied in the extensive interpretation of the

7 Such as the possession of specific knifes, assault, or stalking, etc.

8 Before this period usually the suspect has already been held in police custody for 3 days. In cases that need extensive investigation the maximum period can be prolonged by starting the trial 'pro forma.' Discussing the substance of the case is then (even repeatedly) extended for a maximum of 3 months, as is the suspect's pre-trial detention.

9 Such as molesting your neighbour or threatening your ex-wife with a gun. 
risk of repetition as well as in the interpretation of the seriously shocked legal order. Both arguments seem to aim at safeguarding society from possibly dangerous individuals and dangerous conduct. Judges who decide on pre-trial detention also consider themselves to be some sort of 'first aid,' or in the words of one judge referring to the popular television series 'it is sort of ER.' A judge tries to find an immediate solution for the problem - a possible dangerous person - posed to him. He (demonstrates that he) eliminates this danger by incapacitating the suspect. At the same time, this danger does not need to be very specific. In fact, dangerous are all suspects of more or less serious crimes.

\subsubsection{Presuming Guilt and Punishing Already}

Besides using pre-trial detention for incapacitation, several judicial arguments suggest that pre-trial detention is closely connected to the final sentencing decision. The argumentation comes down to the idea that pre-trial detention is a good way to have a swift and adequate answer to crime. This approach must be understood against the background of the fixed time limits for pre-trial detention in the Dutch Code of Criminal Procedure. Knowing a case will be tried within a period of 104 days, judges are actually already settling a case by using pre-trial detention as a 'pre-punishment.' One judge says, 'the question is whether you think the case has to be settled immediately.' Another one explains, 'thus one estimates how much punishment will finally be imposed, and you let him do his time now; he will then be done by the time he is sentenced.' It thus seems that when judges expect the trial judge to impose a prison sentence, they think it better to start with that sentence already. This is not only favourable for society but also for the suspect. One judges alleges that some suspects even tell him that now they have confessed they want to deal with prison right now, for their lives have been messed up anyhow. They just want to get it over with and start again.

One could ask how judges can possibly punish someone who is not found guilty yet. The interviewed judges would probably answer that this guilt is very likely to be established at trial. As mentioned in section 3.1.1 pre-trial detention requires the available evidence to reach the level of 'grave suspicions.' In the interviews the judges were told that this standard was met in the cases that were discussed. It appears that to the judges' opinion grave suspicions are almost equal to the evidentiary standard that is necessary for conviction. Judges point out that it is therefore almost impossible to not order pre-trial detention in case of grave suspicions. Some judges also indicate that the PoI is defeated in case of strong evidence against the suspect. Opinions vary as to what the exact strength should be. Strong evidence can be 'when the suspect confesses,' when 'the case is more or less decided,' or just in case 'there are grave suspicions.' As a consequence, the grave suspicions are actually one of the two main pillars a decision on pre-trial detention rests upon. The other pillar is, logically, the expectation of whether a prison sentence of a certain length will be imposed. If judges estimate that the suspect will be found guilty, and it is also to be expected that he will receive a prison sentence for at least the length of his pre-trial detention, it is common practice to order pre-trial detention. 


\subsection{Dutch Judicial Argumentation in National and International Context}

The above described Dutch pre-trial detention practice almost seems to be the opposite of the very restricted pre-trial detention Duff defends on the basis of the PoI. Pre-trial detention is not used restrictedly; based on the idea we are dealing with a yet innocent person. It is rather applied extensively for incapacitation, swift adjudication and quick retaliation of the suspected crime; supported by the judicial expectation that the suspect will be convicted to a prison sentence of certain length. Hence, two new presumptions could be formulated: 'the suspect is dangerous,' and 'this suspect will receive a prison sentence.' Dutch judges, then, seem to be violating the PoI as supported by Duff. Nonetheless, their approach is part of a larger development in Dutch national penal law and public policy making. A development that is based on the paradigm 'being tough on crime' - especially crime that includes all kinds of violence that could explain the 'seriousness' label described in section $3.1^{10}$ - and more in particular, is focused on incapacitation. ${ }^{11}$ One example is the expansion of the pre-trial detention regulation for allowing repeat offenders to be pre-detained for petty crimes, ${ }^{12}$ and the policy that, when convicted, these offenders are to be placed in a special Institution for Habitual Offenders (Inrichting voor Stelselmatige Daders) only if they are predetained. A recent legislative initiative furthermore demonstrates the more punitive approach of pre-trial detention - i.e., the connection between pre-trial detention and quick retaliation. The last few years it has been policy to adjudicate specific types of violence (e.g., violence during New Year's Eve, or violence against ambulance personnel) within expedited proceedings. In the same breath ${ }^{13}$ the suspect is arrested, held in custody during investigation, judged and sentenced. These proceedings are now made possible by pre-detaining the suspect for exactly that purpose: expedited proceedings. ${ }^{14}$

The former demonstrates that it is not only Dutch judges who operate from a presumption of dangerousness and 'convictability.' It is rather Dutch political reality that builds the scene. That raises the question whether the characteristics of Dutch pre-trial detention policy and practice can be found in other liberal democracies too. A satisfactory answer to that question would require a profound study of various other national practices. Quite a number of national legal and empirical studies on pre-trial detention have been done. However, a profound comparison of all these different studies with different research questions is beyond the scope of this article. I will therefore look into the available data more eclectically and

10 In recent years many legislative initiatives have passed in which all kinds of violence are tackled one way or another: violence against police officers, against ambulance staff, during special events, during a night out, etc. See Stevens, 'Incapacitation by Pre-trial Detention,' 104-5.

11 See, e.g., M. Malsch \& M. Duker, 'Introduction,' in Incapacitation: Trends and New Perspectives, ed. M. Malsch et al. (Surrey: Ashgate Publishing, 2012), 1-13.

12 M. Boone \& M. Moerings, 'Growing prison rates, in Dutch prisons,' in Dutch prisons, ed. M. Boone et al. (The Hague: Boom Legal Publishers, 2007), 51-74.

13 This can be either 3 or 17 days.

14 A bill that aims to facilitate this practice is pending, see (Parliamentary Papers) Kamerstukken II 2011/12, 33360 . 
accordingly formulate a beginning of an answer - or at least a presumption that would be the beginning of further research into the question.

The increasing use of pre-trial detention is a problem in several European countries. ${ }^{15}$ The same is true with regard to overpopulation of prisons. While prisons are largely occupied by pre-trial detainees, the European Commission is making efforts to reduce their number. ${ }^{16}$ Reasons that underlie extensive use of pre-trial detention can be manifold. A country may have an inadequate legal framework in which, for example, alternatives to pre-trial detention or limits on its duration are absent. Pre-trial detention might also be routinely prolonged, or could be abused to obtain confessions. ${ }^{17}$ All this does not necessarily imply the abandonment of a PoI that prescribes restrictive use of pre-trial detention. Nevertheless, there are several indications that practices work with other presumptions than that of innocence. In France for example, 'the seriousness of the offence' seems to be an important and even decisive factor in the pre-trial detention decision. ${ }^{18}$ Also, it appears from French research that pre-trial detention is used as a tool for incapacitating suspects, ${ }^{19}$ that pre-trial detention is based on reasons other than those recognized by law, ${ }^{20}$ or in fact mainly hinges upon the question whether the suspect is guilty or not. ${ }^{21}$ Furthermore, studies of international youth justice demonstrate that the idea of pre-trial detention as a 'short sharp shock' is not only part of public policy in the Netherlands but also in Germany and France. ${ }^{22}$ More in general, legislation and practice in European countries increasingly permit pretrial measures for preventive purposes unconnected with the criminal process. ${ }^{23}$ Research carried out in Australia shows that punitive attitudes of police and bail granting authorities were found to be a key factor in higher remand rates in Southern Australia. ${ }^{24}$ According to Australian researchers this indicates, as do restrictions on bail eligibility (for example the possibility to restrict bail to limit the worry and anxiety of the victims) and high remand rates, that broader penal concerns about danger and risk associated with particular types of offenders and

15 A.M. van Kalmthout, M.M. Knapen, \& C. Morgenstern (eds.), Pre-trial Detention in the European Union, (Nijmegen: Wolf Legal Publishers, 2009).

16 European Commission's Green Paper on mutual recognition of non-custodial pre-trial supervision measures [COM 2004/562].

17 E. Cape, Z. Namoradze, R. Smith, \& T. Spronken, Effective Criminal Defence in Europe (Antwerp: Intersentia, 2010), in particular 552-53.

18 This can be discerned from the ECtHR case law. See Stevens, 'Pre-Trial Detention,' 166-67.

19 Cape et al., Effective Criminal Defence in Europe, 552-53.

20 D. Pager, 'The Republican Ideal? National Minorities and the Criminal Justice System in Contemporary France,' Punishment \& Society 10 (2008): 375-400, in particular 384-88.

21 J. Hodgson, French Criminal Justice. A Comparative Account of the Investigation and Prosecution of Crime in France (Oxford: Hart Publishing, 2005), 216.

22 J. Muncie, 'Juvenile Justice in Europe: Some Conceptual, Analytical and Statistical Comparisons,' ChildRight 202 (2003): 14-17.

23 Stefano Ruggeri (ed.), Liberty and Security in Europe. A Comparative Analysis of Pre-trial Precautionary Measures in Criminal Proceedings (Osnabrück: V\&R unipress, 2012).

24 D. Bamford, S. King, \& R. Sarre, Factors Affecting Remand in Custody: a Study of Bail Practices in Victoria, South Australia and Western Australia (Canberra: Australian Institute of Criminology Research and Public Policy Series, 1999). 
crimes are reflected in the use of pre-trial detention. ${ }^{25}$ Australian practice and policy thus seem to reflect a situation or development that is similar to what is seen in the Netherlands. Australian scholars also designate this practice as that 'custodial remand is being used as a tool for punishment and to promote law and order policies such as being tough on crime and criminals. ${ }^{26}$ The same seems to be true for Canada about which is said that 'Canada's growing remand population is largely the product of an increasing culture of risk aversion which is permeating the entire criminal justice system.'27

As said, the above is a compilation of pre-trial detention policies and practices in various countries, not a profound and complete portrait of pre-trial detention universally. The compilation nevertheless indicates that pre-trial detention in several contemporary liberal democracies, neither in public policy nor in practice, is restricted by a PoI. Moreover, pre-trial detention seems to operate from a presumption of dangerousness and an expectation of trial outcome. Both imply a more extensive use of pre-trial detention.

\section{No PoI?}

The analysis of the PoI has shown that in relation to pre-trial detention different interpretations of the principle exist. There is the PoI of the ECtHR: a fundamental principle for the restriction of pre-trial detention that is actually not very restricting. Next, there are the PoI that various scholars advocate. Common to those PoI is the idea that pre-trial detention should be a last resort. However, no agreement exists on which criteria follow from that idea of last resort. A criterion the one scholar justifies on the basis of the PoI is rejected by someone else invoking that same PoI. Finally, little is seen of the PoI in pre-trial detention practice. For that matter, it is perhaps characteristic how some Dutch judges interpret the PoI. They believe the PoI is defeated by the presence of a certain level of suspicion. Such an interpretation demonstrates how pre-trial detention is actually used, not only in the Netherlands but in other countries of the Western world as well: it is applied rather extensively, not for restricted reasons but for prevention and quick punishment.

Now, what does the foregoing mean for the pre-trial detention PoI Duff and others advocate? Two points are worth noting here. First, the fact that the PoI does not seem to be a discriminating argument with regard to a specific pre-trial detention model, indicates that there is more to such a position than the PoI reveals. This 'more' are the implicit preferences (such as a system one is familiar (2011): 24-40.

26 S. King, D. Bamford, \& R. Sarre, 'The Remand Strategy: Assessing Outcomes,' Current Issues in Criminal Justice 13 (2003): 327-44; T. Booth \& L. Townsley, 'The Process is the Punishment: The Case of Bail in New South Wales,' Current Issues Crim. Just. 21 (2009-2010): 41-58.

27 C.M. Webster, A.M. Doob, \& N.M. Meyers, 'The Parable of Ms Baker: Understanding Pre-Trial Detention in Canada,' Current Issues Crim. Just. 21 (2009-2010): 79-102. 
with) and ideals of the person invoking the PoI. Not the PoI, but these preferences ultimately account for the advocated scope of pre-trial detention. Whenever interests are weighed, the outcome of that process is largely determined by the interests that are acknowledged to be at stake and the weight that is attached to them. ${ }^{28}$ Thus, choices with regard to an acceptable pre-trial detention are made because a certain weight is attached to the suspect's right to liberty (or, in Duff's account, civic trust) in relation to a public interest of having the suspect's liberty (civic trust) restricted. It seems that when scholars use the PoI as an argument for or against a certain pre-trial detention the PoI actually represents, or perhaps absorbs, the weight that they attach to the interests at stake. Duff does make his preferences explicit when he admits his PoI is influenced by an Anglo-American perspective. That admission could, to a continental European, explain his preference for bail (not common on the continent) and his disapproval of pre-trial detention (much more common on the continent). Less explicit but I believe central to his argument, is Duff's assumption that pre-trial detention is largely to be justified on grounds that serve the trial itself (i.e., the risk of the suspect fleeing to escape trial and the risk of the suspect interfering with the process). ${ }^{29}$ Duff is reluctant or even rather negative about pre-trial detention for preventive reasons. To my mind, mainly these preferences with regard to the purposes of pre-trial detention define Duff's PoI.

In sum, the PoI seems to be the kind of principle that, concerning pre-trial detention, is open to various interpretations and does not give much specific guidance. ${ }^{30}$ It thus functions on a rather abstract level. That brings me to the second point. The stringent PoI Duff but also other scholars advocate, does not seem to be present in practice. At least, the ECtHR allows (PoI based) pre-trial detention to restrict the suspect's right to liberty for preventive reasons, on the basis of little evidence of guilt, and for relatively long periods of time. Furthermore, in pre-trial detention practice as well as in national policy, the PoI even seems to be almost absent. Pre-trial detention is used extensively, for preventive purposes and swift punishment, presuming guilt and dangerousness. This means that Duff's PoI is rather an ideal than a principle with normative effect. Nevertheless, Duff presumes that his PoI, at least to a certain extent, is based in (the use of) regulation on pre-trial detention. He thus presumes his PoI is more than an ideal. However, the pre-trial detention practice described above seems to falsify his presumption.

What to do next with the PoI (plural) described above? Should we abandon the apparently unrealistic ideal of a restricted pre-trial detention? Should we stop

28 See also M. Borgers \& E. van Sliedregt, 'The Meaning of the Precautionary Principle for the Assessment of Criminal Measures in the Fight against Terrorism,' Erasmus Law Review 2 (2009): 191.

29 From that perspective, the distinction between bail and pre-trial detention also makes sense: with bail you retain some trust, while pre-trial detention implies a complete lack of trust that the suspect will not hinder the trial.

30 See also Elies van Sliedregt, Ten to one. A contemporary reflection on the presumption of Innocence (The Hague: Boom Legal Publishers, 2009), 27 and 31. 
invoking the PoI when regulation of pre-trial detention is concerned? The answer depends on what is one's ambition. My main concern would be how to regulate a pre-trial detention practice that has become deaf to the 'last resort' argument. It is inevitable, I believe, to accept the system as it is - at least to a certain extent. Restriction of pre-trial detention for incapacitation for example, can only be discussed if this ground is actually accepted, and balanced with other interests at stake such as the suspect's interest to go to school, to work, to get psychiatric help, to have a family life, etc. It could then also be acknowledged that pre-trial detention for incapacitation seems to function as just one of the (also non-criminal) possibilities of preventive detention (detention of psychiatric patients, football hooligans, terrorists, preventive detention of dangerous convicts, etc.). ${ }^{31}$ In that light, it could be considered whether, in which kind of cases, and under which circumstances there are (less intrusive) alternatives for pre-trial detention in order to prevent a specific danger. Moreover, it is important to stress that pretrial detention remains inseparably connected to the criminal trial and hence the question whether the suspect is (not) guilty and deserves a punishment. Hence, the relation between the suspect's preventive pre-trial detention and his subsequent trial should not become obscured. This means that the length of pre-trial detention must always be proportionate in relation to the expected sentence, and that, if the suspect is finally acquitted, he should be compensated for the time he spent in pre-trial detention.

These are just some examples of issues that should be discussed. Within that process, the PoI does have an important meaning, albeit a limited one. It's function is to remind us of the legal protection function of criminal procedure and as such, a reminder that depriving the suspect of his liberty should be justified within the context of that criminal procedure. ${ }^{32}$ The PoI is not the final argument of what pre-trial detention should look like, but actually the start of the discussion. No more, and no less.

31 See furthermore Stevens 'Voorlopige hechtenis in tijden van risicomanagement,' s. 5.2.

32 See also Marianne F.H. Hirsch Ballin, Anticipative Criminal Investigation. Theory and Counterterrorism Practice in the Netherlands and the United States (The Hague: T.M.C. Asser Press, 2012), 54. 